Jurnal Indonesia Sosial Teknologi: p-ISSN: 2723 - 6609

e-ISSN : 2745-5254

Vol. 2, No. 11 November 2021

\title{
PERANCANGAN SISTEM INFORMASI RESUME MEDIS PASIEN RAWATINAP DI SILOAM HOSPITALS PURWAKARTA
}

\author{
Risa Juli Saputra ${ }^{1}$, Sali Setiatin ${ }^{2}$, Yuda Syahidin ${ }^{3}$ \\ Politeknik Piksi Ganesha, Bandung ${ }^{1,2,3}$ \\ Email: risajulisaputra1996@gmail.com ${ }^{1}$, sali.setiatin@ @iksi.ac.id ${ }^{2}$, \\ yuda.syahidin@piksi.ac.id ${ }^{3}$
}

\begin{abstract}
Abstrak
Rumah sakit merupakan fasilitas pelayanan kesehatan yang memberikan pelayanan secara lengkap. Salah satu parameter untuk menentukan mutu pelayanan kesehatan di rumah sakit adalah data atau informasi dari rekam medis, khususnya pada resume medis dan untuk mengetahui kelengkapan pengisian resume medis perlu dilakukan analisis. Namun penginputan analisis secara manual dan belum adanya sistem khusus dapat mengurangi efesien dan efektifitas waktu, untuk itu penelitian ini dibuat bertujuan merancang sistem informasi khusus analisis resume medis pasien rawat inap agar mempermudahkan petugas didalam mengalisis. Penelitian ini menggunakan metode kualitatif dengan metode pengembangan perangkat lunak air terjun / Waterfall dan lokasi penelitian ini adalah di Siloam Hospitals Purwakarta dengan menggunakan teknik pengumpulan data observasi dan wawancara. Masalah yang terjadi dalam menganalisis kelengkapan resume masih dikerjakan dengan input manual pada exel, seperti menginput nomor rekam medis, nama pasien, nama dokter dan bahkan jumlah hari perawatan masih dihitung manual sehingga tidak menutup kemungkinan akan terjadinya kekeliruan dalam penginputan. Adapun hasil observasi persentase dari 200 sampel berkas resume medis rawat inap di Siloam Hospitals Purwakarta adalah 65\% untuk berkas yang lengkap dan 35\% untuk yang tidak lengkap. Saran yang dapat diberikan oleh penulis agar rumah sakit dapat meningkatkan sistem informasi yang lebih modern untuk penginputan dan pengolahan data.
\end{abstract}

Kata Kunci : perancangan; resume medis rawat inap; waterfall.

\begin{abstract}
The hospital is a health service facility that provides complete services. One of the parameters to determine the quality of health services in hospitals is data or information from medical records, especially on medical resumes. However, manually inputting analysis and the absence of a special system can reduce efficiency and time effectiveness, for this reason this study was made aimed at designing a special information system for analyzing medical resumes for inpatients to make it easier for officers to analyze. This study uses a qualitative method with the waterfall software development method and the location of this research is at Siloam Hospitals Purwakarta using observation and interview data collection techniques. Problems that occur in analyzing the completeness of the resume are still being done with manual input in Excel, such as inputting medical record numbers, patient names,
\end{abstract}


doctor names and even the number of days of treatment is still calculated manually so it does not rule out the possibility of errors in inputting. The percentage of observation results from 200 samples of inpatient medical resume files at Siloam Hospitals Purwakarta is $65 \%$ for complete files and $35 \%$ for incomplete files. Suggestions that can be given by the author so that the hospital can improve a more modern information system for data input and processing.

Keywords: design; inpatient medical resume; waterfall

\section{Pendahuluan}

Rumah sakit adalah institusi pelayanan kesehatan perorangan secara paripurna yang menyediakan rawat inap, rawat jalan dan gawat darurat (Permenkes RI No.3/MENKES/PER/2020). Era saat ini adalah era informasi, dan masyarakat perlu meningkatkan pengetahuannya, termasuk di bidang kesehatan (Jaya, Wulandari, \& Susiloningtyas, 2021). Sebagai penyedia informasi kesehatan, rumah sakit harus mampu memberikan pelayanan informasi yang cepat dan akurat. Rumah sakit adalah tempat pasien mencari dan menerima pelayanan medis, serta tempat pendidikan klinis mahasiswa kedokteran, perawat dan berbagai tenaga kesehatan lainnya (Kurniati, 2019).

Kesehatan murupakan kebutuhan yang harus diperoleh oleh setiap orang dan fasilitas kesehatan yang mampu memberikan pelayanan kuratif dan rehabitatif kepada pasien salah satunya adalah Rumah Sakit. Menurut Permenkes No. 4 Tahun 2018 tentang kewajiban rumah sakit dan kewajiban pasien bahwa fasilitas pelayanan kesehatan dalam mencapai mutu sebaiknya memberikan pelayanan yang baik kepada pasien, tersedianya data yang lengkap dan akurat untuk meningkatkan kualitas pelayanan kesehatan.

Salah satu parameter untuk menentukkan mutu pelayanan kesehatan di rumah sakit adalah data atau informasi dari rekam medis yang baik dan lengkap. Rekam medis merupakan salah satu bagian penting dalam membantu pelaksanaan pemberian pelayanan kepada pasien di rumah sakit. Hal ini berkaitan dengan isi rekam medis yang mencerminkan segala informasi menyangkut pasien sebagai dasar dalam menentukan tindakan lebih lanjut dalam upaya pelayanan maupun tindakan medis lain. Menurut Permenkes No. 269/Menkes/Per/III/2008 tentang rekam medis, rekam medis adalah berkas yang berisikan catatan dan dokumen tentang identitas pasien, pemeriksaan, pengobatan, tindakan dan pelayanan lain yang telah diberikan kepada pasien. Salah satu isi dari rekam medis adalah resume medis rawat inap. Resume medis adalah ringkasan pulang pasien yang telah diberikan oleh tenaga kesehatan terkait dari awal perawatan dan pengobatan hingga pasien pulang (Hatta, 2012).

Dalam pelayanan kesehatan tidak terlepas dari perkembangan teknologi agar mampu memberikan pelayanan kesehatan masyarakat secara lebih efisien, meningkatkan efektivitas dan produktivitas kerja serta menguatkan fungsi stratejik organisasi kesehatan masyarakat dengan memanfaatkan informasi kesehatan dari berbagai sumber. Dengan demikian seorang praktisi kesehatan masyarakat harus mampu menggunakan informasi kesehatan secara efektif dan mampu mengembangkan, mengelola serta memelihara program teknologi informasi kesehatan masyarakat secara efektif (Taryanto \& 
Handayani, 2019). Perubahan teknologi saat ini sangat pesat dan kita dituntut guna dapat mengimbangi perkembangan teknologi tersebut karena kebutuhan penggunaan teknologi yang sangat meningkat. Teknologi informasi digunakan untuk memudahkan manusia dalam memproduksi data, mengolah data hingga menyebarkan informasi.

Sistem informasi ialah salah satu hal yang sangat vital dalam menjalankan sarana pelayanan kesehatan termasuk di dalamnya fasilitas kesehatan rumah sakit. Terutama pada era digitalisasi saat ini karena perkembangan teknologi yang terjadi beberapa tahun terakhir meningkat pesat. Sistem yaitu suatu jaringan kerja yang saling berkaitan dan menyatu untuk mencapai jaringan tertent (Ramadani \& Heltiani, 2019). Sistem adalah suatu unsur yang saling berkolerasi secara sistematis untuk sampai pada suatu unsur dalam batas-batas lingkungan tertentu, atau suatu unsur yang saling bertautan untuk mencapai satu arah atau sistem yang terdiri dari kesatuan beberapa unsur (Putra \&

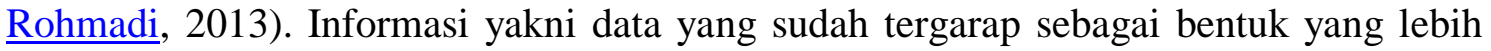
bermanfaat \& bermakna untuk penggunanya (Prasetyo \& Azis, 2018).

Rumah sakit merupakan suatu lembaga organisasi yang harus mempunyai rekam medis sebagai bukti autentik tentang pelayanan yang diberikan petugas kepada pasien selama di rumah sakit, salah satu bagian yang utama dalam rekam medis yaitu formulir resume medis pasien rawat inap. Untuk itu perlu dilakukan pengolahan data dengan menganalisis isi resume medis untuk mengetahui tingkat keakuratan dan kelengkapan isi resume medis pasien rawat inap.

Pengolahan data yang dikerjakan secara manual memiliki banyak kekurangan salah satunya membutuhkan waktu yang cukup lama, ketidak akuratan data dan kemungkinan kesalahan yang besar. Oleh karena itu sangat penting dilakukan input data secara elektronik untuk mengefisienkan proses input data serta mengurangi angka ketidak akuratan hasil akhir dari perhitungan kelengkapan isi resume medis pasien.

Berdasarkan observasi dan wawancara kepada kepala bagian rekam medis dan petugas perekam medis dibagian analisis yang dilakukan penulis pada tanggal 02 september 2021 bahwa di Siloam Hosptals Purwakarta, telah dilakukan anasis kelengkapan resume medis rawat inap dengan komputerisasi namun belum ada aplikasi khusus dan masih sering terjadi ketidaklengkapan pengisian berkas rekam medis rawat inap salah satunya adalah resume medis. Masalah yang sering tidak lengkap dalam pengisian resume medis adalah indikasi pasien dirawat, diagnosa pasien, tindakan dokter, obat yang diberikan dan nama dokter. Berdasarkan penelitian, dari 200 sampel berkas terdapat 131 formulir resume medis yang lengkap dan 69 formulir resume medis yang belum lengkap. Persentase untuk kelengkapan resume medis tersebut adalah $65 \%$ dan untuk ketidaklengkapan resume medis adalah 35\%. Nilai persentase kelengkapan perlu ditingkatkan dan rumah sakit memerlukan sistem informasi khusus untuk mengananalisis kelengkapan resume medis pasien rawat inap. Resume medis wajib diisi lengkap sebab kelengkapan pengisian resume medis ialah salah satu indicator dari kualitas rekam medis, rekam medis bisa dikatakan memiliki nilai kualitas apabila data- data yang dimuat didalamnya diisi secara akurat serta lengkap. 
Pada penelitian yang dilakukan oleh (Syahidin \& Trioktafiani, 2019) membahas tentang perancangan sistem pendaftaran pasien rawat jalan yang menjadi alternatif untuk memudahkan proses pendaftaran pasien rawat jalan.

Penelitian yang dilakukan oleh (Rangga, Syahidin, \& Hidayati, 2021) membahas mengenai mengidentifikasi perancangan sistem informasi kelengkapan rekam medis rawat jalan dengan menggunakan metode V-Model. Tetapi penelitian ini menggunakan variasi dari bentuk waterfall atau yang disebut V-Model. Sehingga penulis merancang aplikasi menggunakan bahasa pemograman php dan framework laravel 6 dengan penyimpanan database $M y S Q L / M a r i a D B$.

Pentingnya penelitian ini yaitu untuk merancang sistem informasi khusus analisis resume medis pasien rawat inap agar mempermudahkan petugas didalam menganalisis kelengkapan.

\section{Metode Penelitian}

Dalam menyelesaikan penelitian ini penulis menggunakan metode penelitian kualitatif dengan pendekatan deskriptif yaitu suatu penelitian yang bertujuan menggambarkan (deskripsi) tentang keadaan tertentu secara objektif. Penelitian dengan tujuan mendeskripsi fenomena dan peristiwa yang terjadi, perlu mendapat perhatian Menurut (Sugiyono, 2014) metode penelitian kualitatif adalah metode penelitian yang digunakan untuk meneliti pada kondisi objek yang alamiah, dimana peneliti adalah sebagai instrument kunci.

Lokasi penelitian adalah di Siloam Hospitals Purwakarta. Adapun Teknik Pengumpulan Data yang digunakan peneliti yaitu menggunakan :

a. Penelitian Lapangan (Observasi)

Metode ini dilakukan dengan cara mengamati secara langsung keadaan dan kegiatan rumah sakit terutama pada bagian rekam medis yang bertugas menganalisis kelengkapan resume rawat inap guna mendapatkan keterangan yang akurat.

b. Wawancara (Interview)

Menurut (Rojabi, 2019) Wawancara merupakan pengumpulan data atau informasi yang dilakukan dengan menggunakan pertanyaan yang disampaikan langsung kepada sumber informasi. Dalam hal ini, peneliti melakukan wawancara dengan petugas rekam medis terutama dengan petugas bagian analisis resume dan kepala rekam medis di Siloam Hospitals Purwakarta

Metode pengembangan perangkat lunak yang digunakan adalah metode Linear sequential atau disebut juga metode Waterfall. Model SDLC air terjun (waterfall) sering juga disebut model sekuensial linier (sequential linear). Metode waterfall merupakan model pengembangan sistem informasi yang sistematik dan sekuensial (Sasmito, 2017). Berikut adalah gambar dan tahapan model waterfall : 


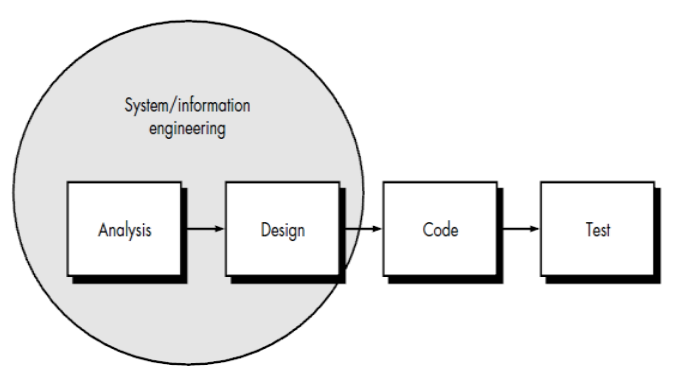

Sumber: Rosa dan Salahudin (2013)

Gambar 1. Model Waterfall

\section{Hasil dan Pembahasan}

Petugas analisis berkas rekam medis rawat inap di Siloam Hospitals Purwakarta telah melakukan pengisian analisis secara rutin khususnya pada formulir resume medis pasien rawat inap, namun penginputan masih dilakukan secara manual dengan menggunakan aplikasi exel dan masih memerlukan sebuah sistem yang lebih akurat yang dapat menghitung analisis lebih cepat serta tidak memakan banyak tempat.

Berdasarkan wawancara yang dilakukan oleh peneliti kepada salah satu petugas anasilis kelengkapan resume medis pasien rawat inap bahwa masih banyak terdapat kekurangan didalam menganalisis menggunakan excel diantaranya :

1. Pengisian nama pasien, nomor RM, nama dokter bahkan perhitungan hari perawatan masih menggnakan manual. Pengisian data dengan manual sangat mungkin terjadinya kesalahan dan memakan lebih banyak waktu.

2. Apabila disaat menginput terjadi error sistem atau ganggaun pada listrik maka data tidak akan tersimpan secara otomatis dan petugas harus menginput ulang dari awal.

3. Jumlah hasil persentase dari kelengkapan belum menampilkan secara otomatis dan petugas analisis belum mengetahui performa kelengkapan pengisian per dokter.

4. Petugas belum bisa mengetahui persentase kelengkapan per ruangan.

Adapun hasil penelitian dari 200 berkas yang dijadikan sampel anasis formulir resume medis pasien rawat inap yang dilakukan petugas sebagai berikut : 


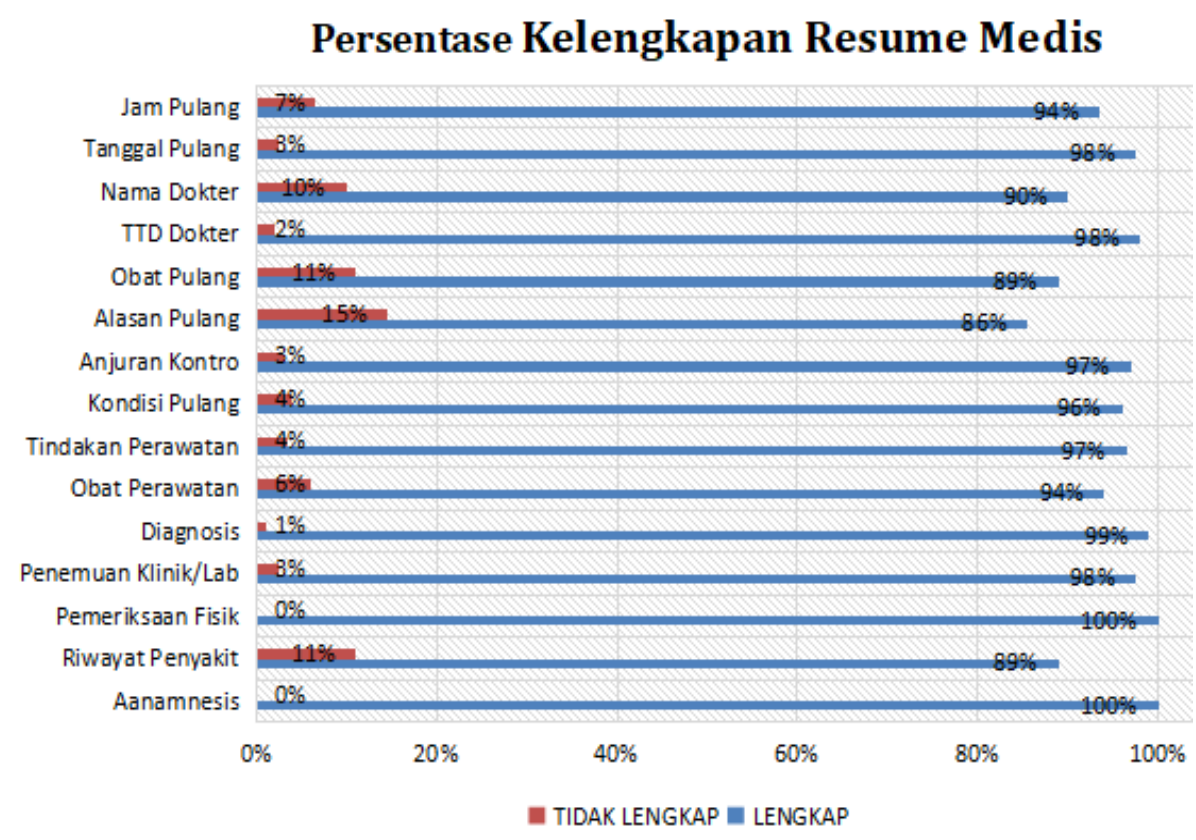

Gambar 2. Grafik Persentase Kelengkapan Resume Medis Sumber : Data Sekunder

1. Anamnesis (Alasan Masuk)

Dari hasil perhitungan, presentase kelengkapan formulir resume medis pasien rawat inap pada Anamnesis sebesar 100\% dari 200 berkas rekam medis, sedangkan untuk yang tidak lengkap sebesar $0 \%$ dari 200 berkas rekam medis

2. Riwayat Penyakit

Dari hasil perhitungan, presentase kelengkapan formulir resume medis pasien rawat inap pada Riwayat Penyakit sebesar 89\% dari 200 berkas rekam medis, sedangkan untuk yang tidak lengkap sebesar 11\% dari 200 berkas rekam medis

3. Pemeriksaan Fisik

Dari hasil perhitungan, presentase kelengkapan formulir resume medis pasien rawat inap pada Riwayat Penyakit sebesar 100\% dari 200 berkas rekam medis, sedangkan untuk yang tidak lengkap sebesar $0 \%$ dari 200 berkas rekam medis

4. Penemuan Klinik

Dari hasil perhitungan, presentase kelengkapan formulir resume medis pasien rawat inap pada Riwayat Penyakit sebesar 97,5\% dari 200 berkas rekam medis, sedangkan untuk yang tidak lengkap sebesar 2,5\% dari 200 berkas rekam medis

5. Diagnosis

Dari hasil perhitungan, presentase kelengkapan formulir resume medis pasien rawat inap pada Diagnosis sebesar 99\% dari 200 berkas rekam medis, sedangkan untuk yang tidak lengkap sebesar $1 \%$ dari 200 berkas rekam medis

6. Obat Selama Perawatan 
Dari hasil perhitungan, presentase kelengkapan formulir resume medis pasien rawat inap pada Riwayat Penyakit sebesar 94\% dari 200 berkas rekam medis, sedangkan untuk yang tidak lengkap sebesar 6\% dari 200 berkas rekam medis

7. Tindakan Selama di Rumah Sakit

Dari hasil perhitungan, presentase kelengkapan formulir resume medis pasien rawat inap pada Riwayat Penyakit sebesar 96,5\% dari 200 berkas rekam medis, sedangkan untuk yang tidak lengkap sebesar 3,5\% dari 200 berkas rekam medis

8. Kondisi Pulang

Dari hasil perhitungan, presentase kelengkapan formulir resume medis pasien rawat inap pada Riwayat Penyakit sebesar 96\% dari 200 berkas rekam medis, sedangkan untuk yang tidak lengkap sebesar 4\% dari 200 berkas rekam medis

9. Anjuran Kontrol Selanjutnya

Dari hasil perhitungan, presentase kelengkapan formulir resume medis pasien rawat inap pada Riwayat Penyakit sebesar 97\% dari 200 berkas rekam medis, sedangkan untuk yang tidak lengkap sebesar 3\% dari 200 berkas rekam medis

10. Alasan Pulang

Dari hasil perhitungan, presentase kelengkapan formulir resume medis pasien rawat inap pada Riwayat Penyakit sebesar 85,5\% dari 200 berkas rekam medis, sedangkan untuk yang tidak lengkap sebesar $14,5 \%$ dari 200 berkas rekam medis

11. Obat Pulang

Dari hasil perhitungan, presentase kelengkapan formulir resume medis pasien rawat inap pada Riwayat Penyakit sebesar 89\% dari 200 berkas rekam medis, sedangkan untuk yang tidak lengkap sebesar $11 \%$ dari 200 berkas rekam medis

12. TTD (Paraf) Dokter

Dari hasil perhitungan, presentase kelengkapan formulir resume medis pasien rawat inap pada Riwayat Penyakit sebesar 98\% dari 200 berkas rekam medis, sedangkan untuk yang tidak lengkap sebesar $2 \%$ dari 200 berkas rekam medis

13. Nama Dokter

Dari hasil perhitungan, presentase kelengkapan formulir resume medis pasien rawat inap pada Riwayat Penyakit sebesar 90\% dari 200 berkas rekam medis, sedangkan untuk yang tidak lengkap sebesar 10\% dari 200 berkas rekam medis

14. Tanggal Pulang

Dari hasil perhitungan, presentase kelengkapan formulir resume medis pasien rawat inap pada Riwayat Penyakit sebesar 97,5\% dari 200 berkas rekam medis, sedangkan untuk yang tidak lengkap sebesar 2,5\% dari 200 berkas rekam medis

15. Jam Pulang

Dari hasil perhitungan, presentase kelengkapan formulir resume medis pasien rawat inap pada Riwayat Penyakit sebesar 93,5\% dari 200 berkas rekam medis, sedangkan untuk yang tidak lengkap sebesar 6,5\% dari 200 berkas rekam medis.

Hasil dari penelitian ini adalah diperolehnya sistem informasi khusus untuk menganalisis kelengkapan resume medis pasien rawat inap berbasis komputer di Siloam Hospitals Purwakarta yang mana pada sebelumnya analisis kelengkapan resume medis 
hanya dilakukan dengan menggunakan aplikasi excel. Dari menginput nama pasien, nama dokter hingga tanda tangan dokter, kemudian tampilan perhitungan hasil persentase dari kelengkapan isi formulir resume medis pasien rawat inap yang telah diisi oleh petugas dan yang terakhir adalah penyajian data dengan menampilkan sebuah grafik.

Berdasarkan hasil penelitian yang telah dilakukan oleh penulis dengan mengambil 200 sampel berkas rekam medis khususnya pada kelengkapan isi resume medis pasien rawat inap di Siloam Hospitals Purwakarta diperoleh nilai persentase kelengkapan tertinggi terdapat pada Anamnesis dan Pemeriksaan fisik dengan angka 100\% yang lengkap dan yang tidak lengkap dengan angka $0 \%$, adapun nilai angka terendah terdapat pada Alasan Pulang dengan angka 85,5\% dan tidak lengkap dengan angka 14,5\%. Data yang diperoleh dalam penelitian ini menunjukkan hasil bahwa dalam pengisian formulir resume medis pasien rawat inap di Siloam Hospitals Purwakarta sudah cukup baik.

Salah satu faktor yang mempengaruhi kelengkapan pengisian rekam medis adalah faktor sumber daya tenaga kesehatan seperti perilaku dokter, paramedis dan petugas kesehatan lainnya (Wirajaya \& Nuraini, 2019). Selain faktor sarana dan prasarana seperti formulir rekam medis, faktor metode atau standar operasional prosedur, beban kerja yang tinggi tentu juga akan mempengaruhi kelengkapan pengisian resume medis. Dampak yang ditimbulkan dari tidak lengkapnya pengisian berkas rekam medis yang terkait dengan hasil pemeriksaan pasien tidak dapat dipertanggungjawabkan isinya jika terjadi suatu masalah yang akan berlanjut di jalur hukum, rumah sakit mungkin tidak dapat mempertahankan akreditasi SNARS yang sudah dicapinya karena kurangnya mutu pelayanan kepada pasien dan jika diagnosa tidak lengkap maka akan berdampak kepada pasien karena tidak mengetahui diagnosa yang diberikan oleh dokter, untuk itu pihak rumah sakit perlu memperhatikan hal ini mengingingat terisinya data rekam medis yang lengkap khususnya pada formulir resume medis pasien rawat inap akan menjadi nilai yang sangat penting.

Berikut flowmap dan diagram conteks yang dirancang di Siloam Hospitals Puwakarta 


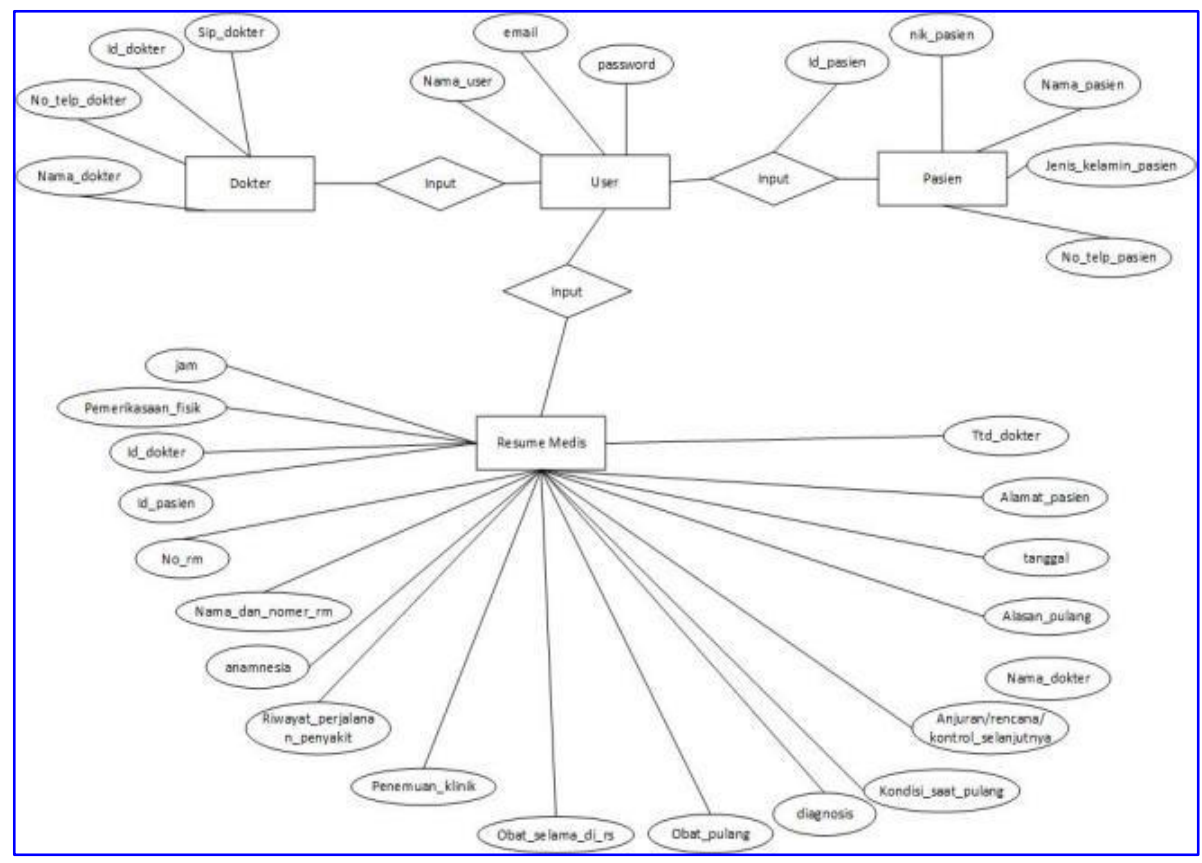

Gambar 3. Diagram conteks yang dirancang

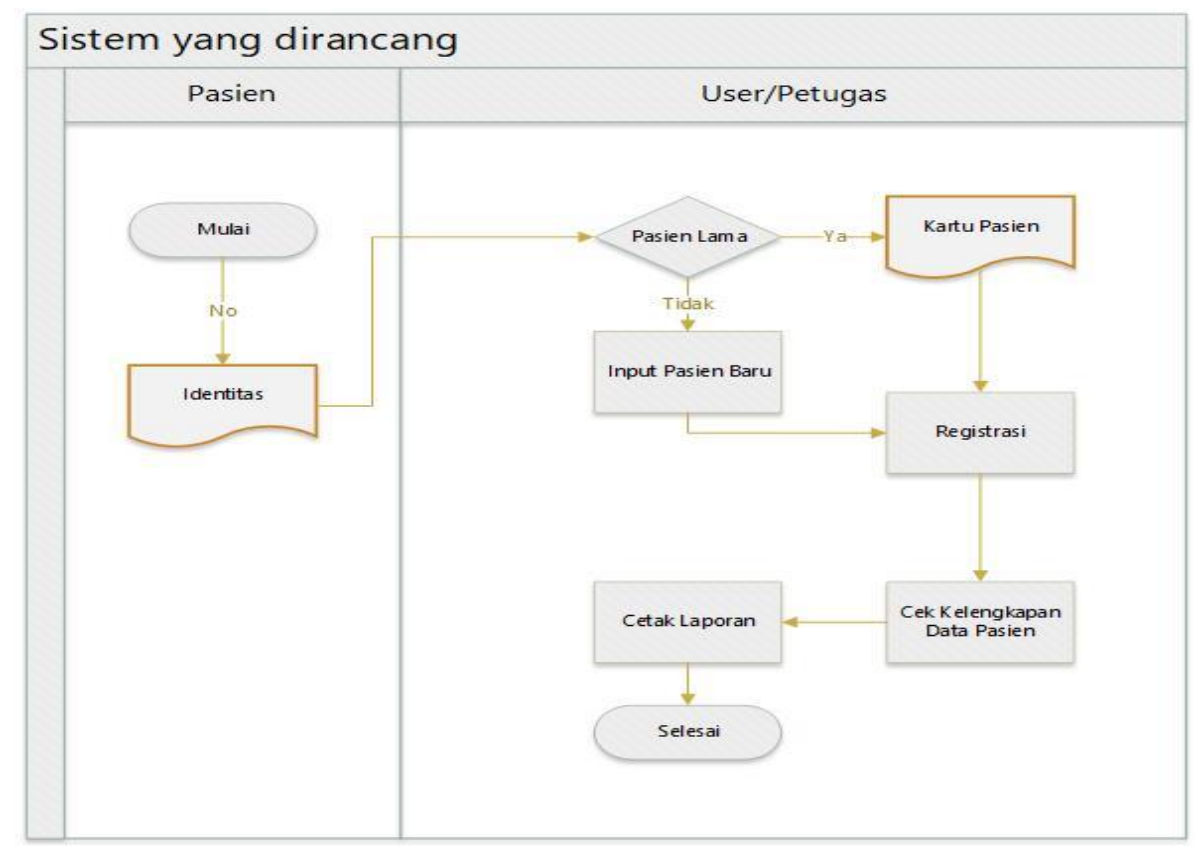

Gambar 4. Flowmap yang dirancang

\section{Implementasi Sistem}

Tahap implementasi program merupakan suatu tahap penerapan dari analisis dan desain sistem yang telah dibuat sebelumnya. Adapun kebutuhan sistem ini terdiri dari kebutuhan akan perangkat keras dan perangkat lunak minimal harus dipenuhi sehingga aplikasi ini dapat berjalan dengan baik.

\section{A. Kebutuhan Perangkat Keras (Hardware)}


Perancangan Sistem Informasi Resume Medis Pasien Rawatinap di Siloam Hospitals

Purwakarta

1. Memory : Minimal $1 \mathrm{~GB}$

2. Storage : Minimal 128

GB

\section{B. Kebutuhan Perangkat Lunak (Software)}

1. Sistem : Linux/

Operasi Windows

2. Database : Mysql/Mari

$a D B$

3. Server: Apache

4. Pemograma : PHP dengan

$\mathrm{n}$

Framework

Laravel 6

\section{Tampilan Antarmuka}

Pada tahapan ini penulis merancang aplikasi menggunakan bahasa pemograman php dan framework laravel 6 dengan penyimpanan database $M y S Q L / M a r i a D B$. Berikut tampilan interface aplikasi :

\section{Halaman Login}

\section{Siloams Hospitals}

\section{Analisis Resume Medis}

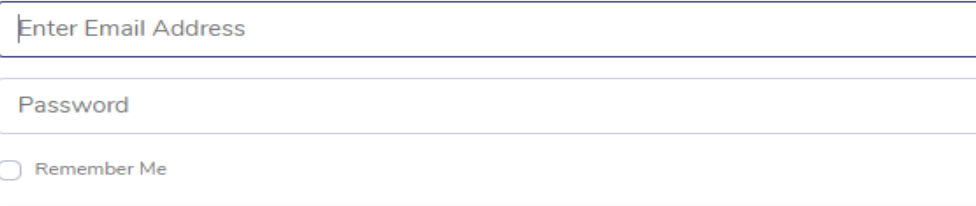

Gambar 5. Halaman Form Login

Halaman ini adalah tampilan awal saat aplikasi dijalankan, pengguna/users harus melakukan login terlebih dahulu untuk bisa masuk kedalam sistem.

Petunjuk pemakaian:

1. Memasukkan email dan password kemudian klik login atau tekan enter.

\section{Halaman Data Resume Medis}




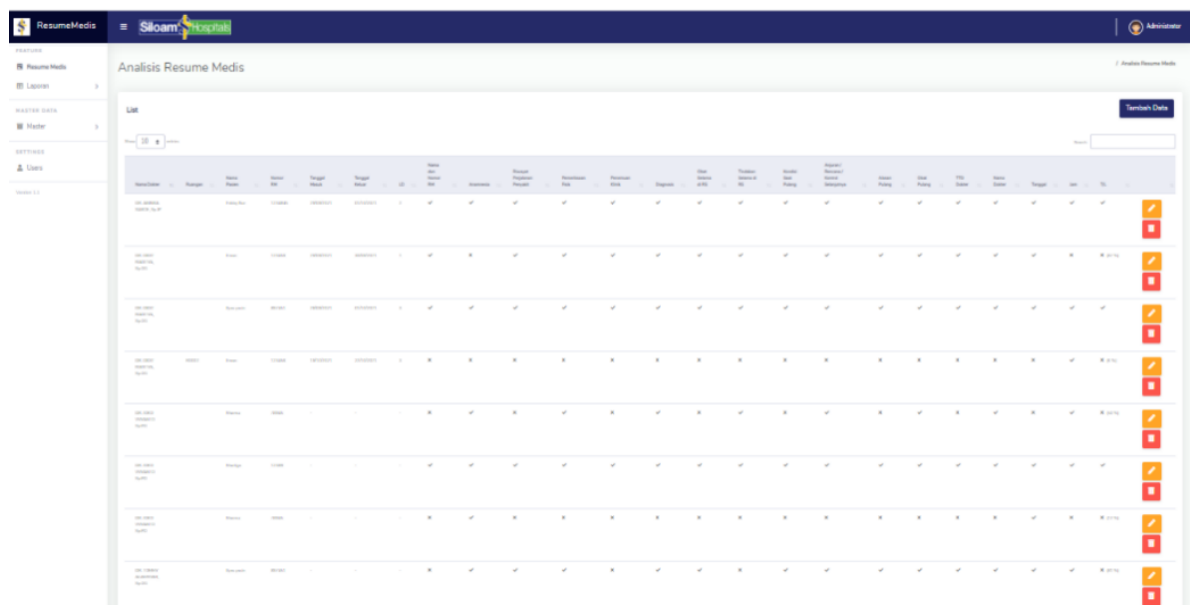

Gambar 6. Halaman Data Resume Medis

Halaman ini adalah tampilan setelah users berhasil masuk, pada halaman ini berisikan data-data resume medis yang sudah terinput.

Petunjuk pemakaian:

1. Halaman ini akan muncul jika menekan menu resume medis

2. Tombol Tambah Data untuk menginputkan data resume medis

3. Textbox untuk melakukan pencarian data resume medis

4. Tombol ikon pensil untuk mengubah data resume medis

5. Tombol ikon tempat sampah untuk menghapus data resume medis

\section{Halaman Input Resume Medis}

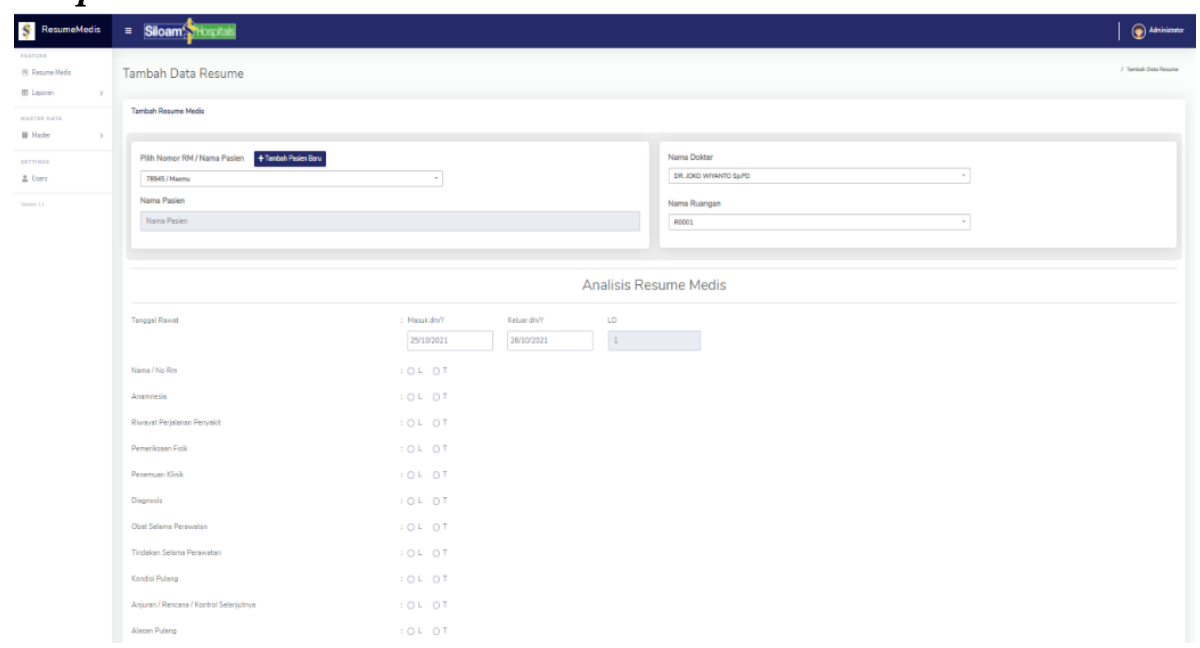

Gambar 7. Halaman Input Resume Medis

Halaman ini adalah tampilan yang berisikan form untuk menginput data pasien. Petunjuk pemakaian:

1. Halaman ini akan muncul jika menekan tombol Tambah Data dihalaman data resume medis 
2. Cari berdasarkan No RM atau Nama Pasien, jika nomor / nama ditemukan maka nama dan nomor RM otomatis terisi, jika pasien tidak ditemukan klik tambah data pasien untuk menginput data pasien baru

3. Pilih tanggal masuk dan keluar untuk menentukan perhitungan LD secara otomatis

4. Pilih kelengkapan data, klik L jika lengkap atau TL jika tidak lengkap

\section{Halaman Ubah Resume Medis}

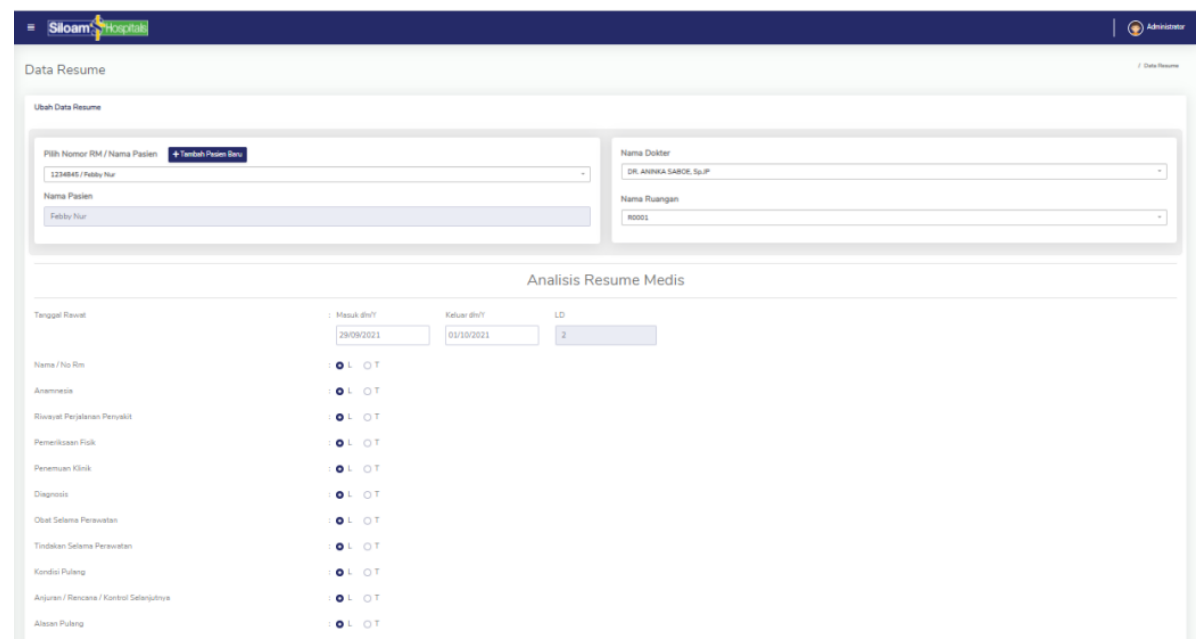

Gambar 8. Tampilan Ubah Resume

Halaman ini adalah tampilan yang berisikan form untuk mengubah data resume. Petunjuk pemakaian:

1. Halaman ini akan muncul jika menekan tombol ikon pensil dihalaman data pasien

2. Ubah data dalam form sesuai dengan kebutuhan

3. Tekan enter atau klik tombol simpan untuk menyimpan data

\section{Halaman Laporan Resume Medis}

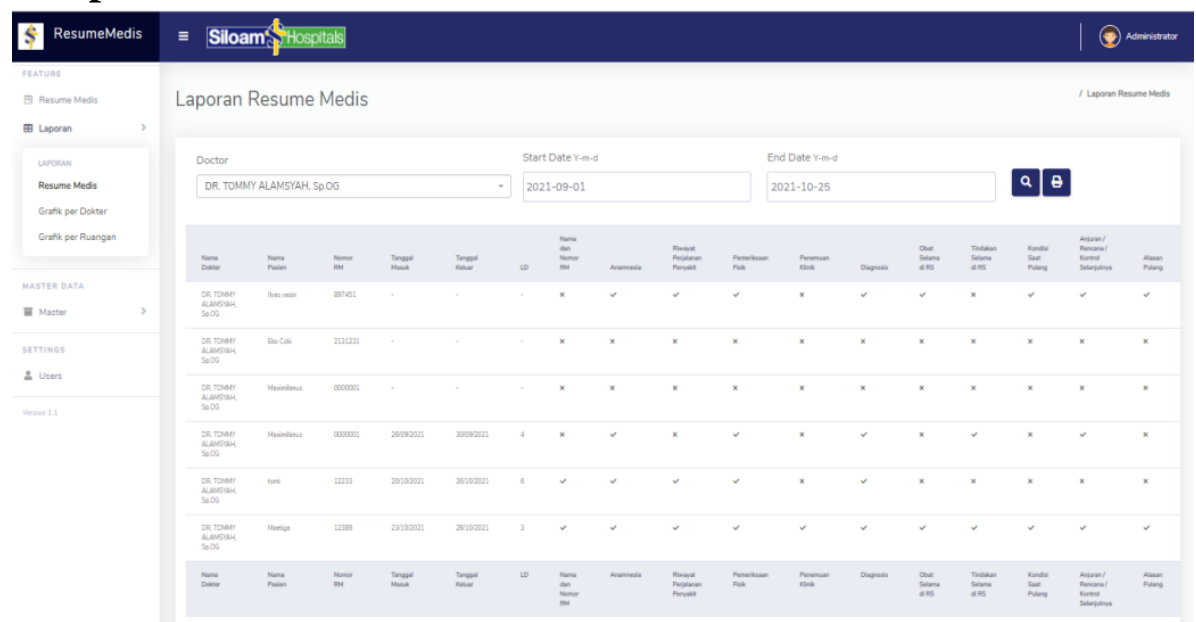

Gambar 9. Halaman Laporan Resume Medis 
Halaman ini adalah tampilan yang berisikan laporan data resume medis yang sudah tersimpan.

Petunjuk pemakaian:

1. Halaman ini akan muncul jika menekan laporan, menu resume medis

2. Pilih Dokter yang akan dicetak laporannya

3. Pilih Start Date untuk acuan tanggal awal

4. Pilih Enda Date untuk acuan tanggal akhir

5. Tombol ikon kaca pembesar untuk menampilkan hasil filter dari pilihan dokter dan range tanggal

6. Tombol ikon print untuk mencetak hasil filter dari pilihan dokter dan range tanggal dalam bentuk PDF

\section{Halaman Print Resume Medis}
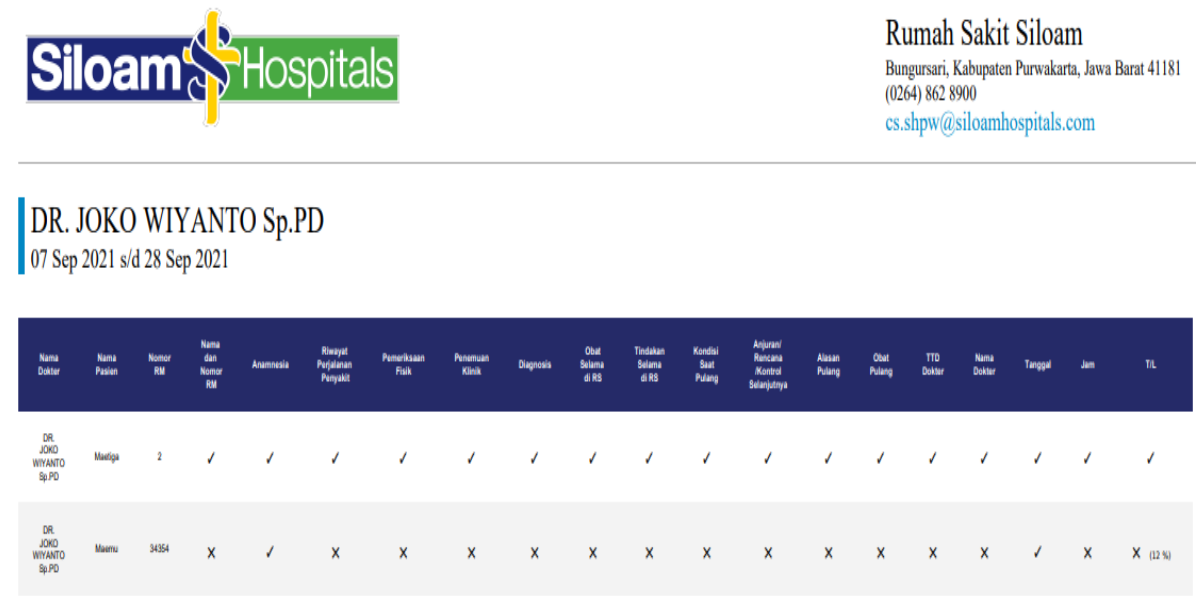

Gambar 10. Hasil Print Laporan Resume Medis

Halaman ini adalah tampilan yang berisikan preview $P D F$ pada saat menekan tombol ikon print di halaman Laporan Resume Medis.

\section{Halaman Laporan Grafik Dokter}




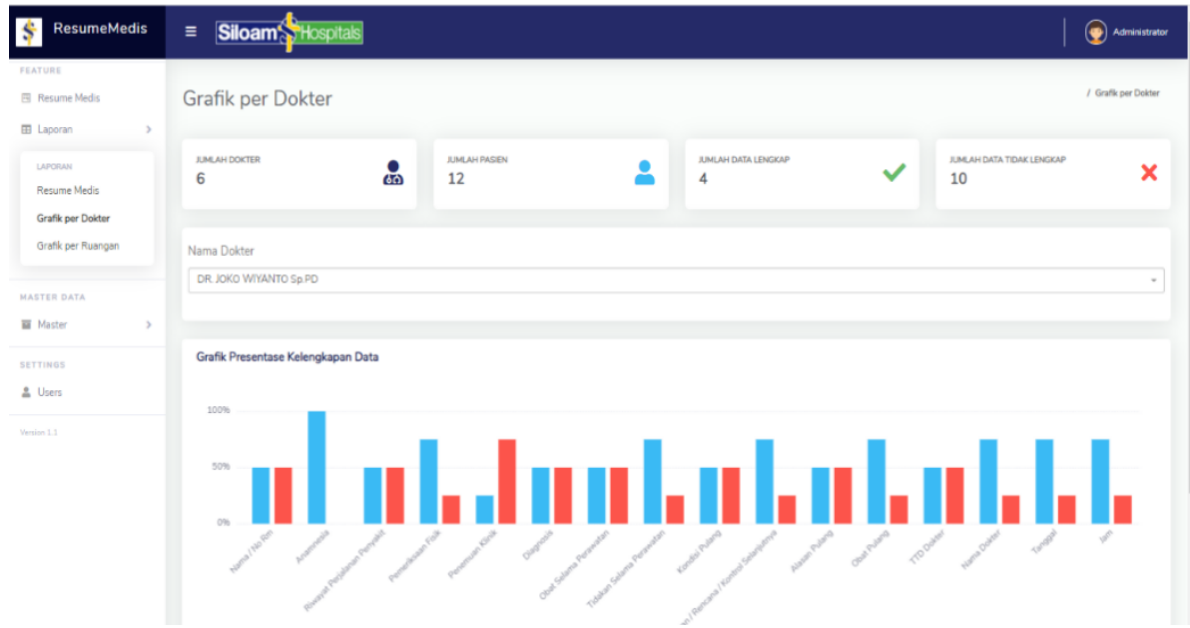

Gambar 11. Laporan Grafik Dokter

Halaman ini adalah tampilan grafik kelengkapan data resume medis dari semua dokter atau berdasarkan per dokter.

Petunjuk pemakaian:

1. Tampilan awal akan menampilkan grafik dari semua dokter

2. Pilih nama dokter untuk menampilkan grafik per dokter.

\section{Halaman Laporan Grafik Ruangan}

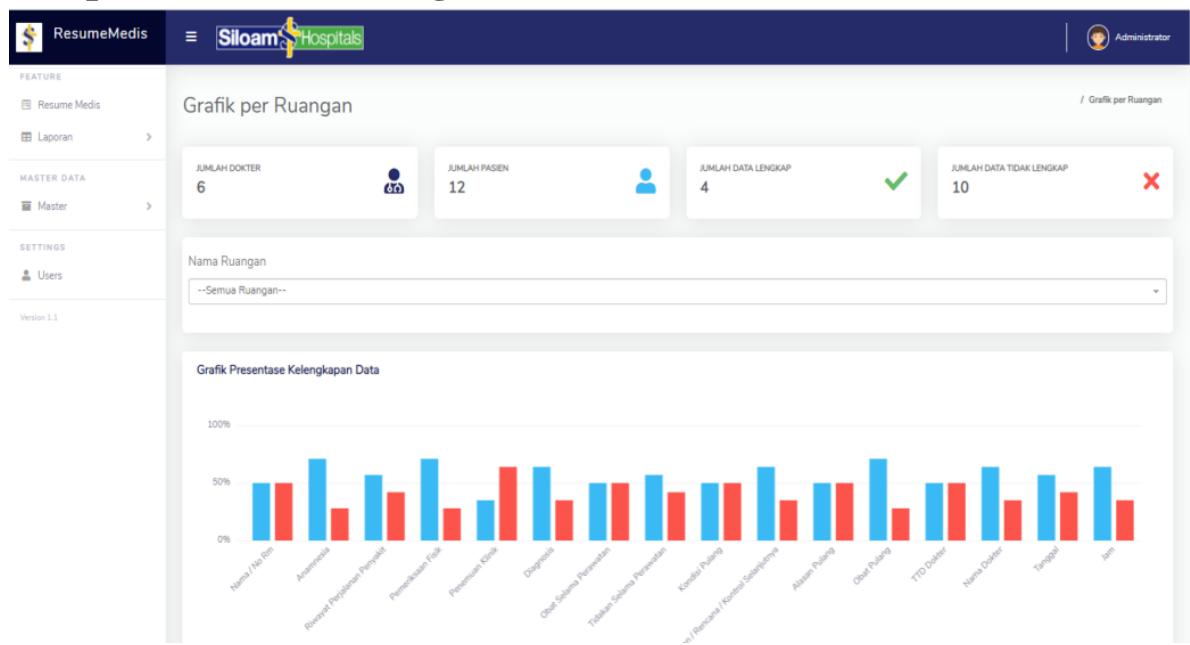

Gambar 12. Laporan Grafik Ruangan

Halaman ini adalah tampilan grafik kelengkapan data resume medis dari semua ruangan atau berdasarkan per ruangan

Petunjuk pemakaian:

1. Tampilan awal akan menampilkan grafik dari semua ruangan

2. Pilih nama ruangan untuk menampilkan grafik per ruangan 


\section{Halaman Master Data Dokter}

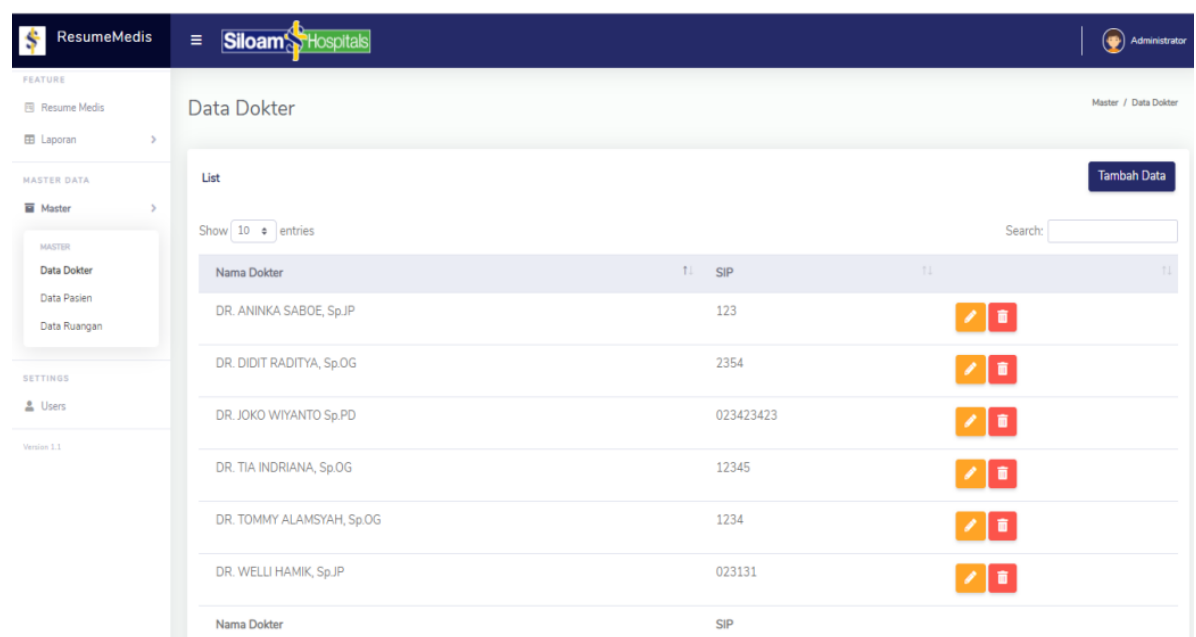

Gambar 13. Halaman Master Data Dokter

Halaman ini adalah tampilan yang berisikan data-data dokter yang sudah terinput. Petunjuk pemakaian:

1. Halaman ini akan muncul jika menekan mеnu Master, data Dokter pada sidebar menu

2. Tombol Tambah Data untuk menginputkan data dokter

3. Textbox untuk melakukan pencarian data dokter

4. Tombol ikon pensil untuk mengubah data dokter yang terdiri dari nama dokter dan SIP

5. Tombol ikon tempat sampah untuk menghapus data dokter

\section{Halaman Input Data Dokter}

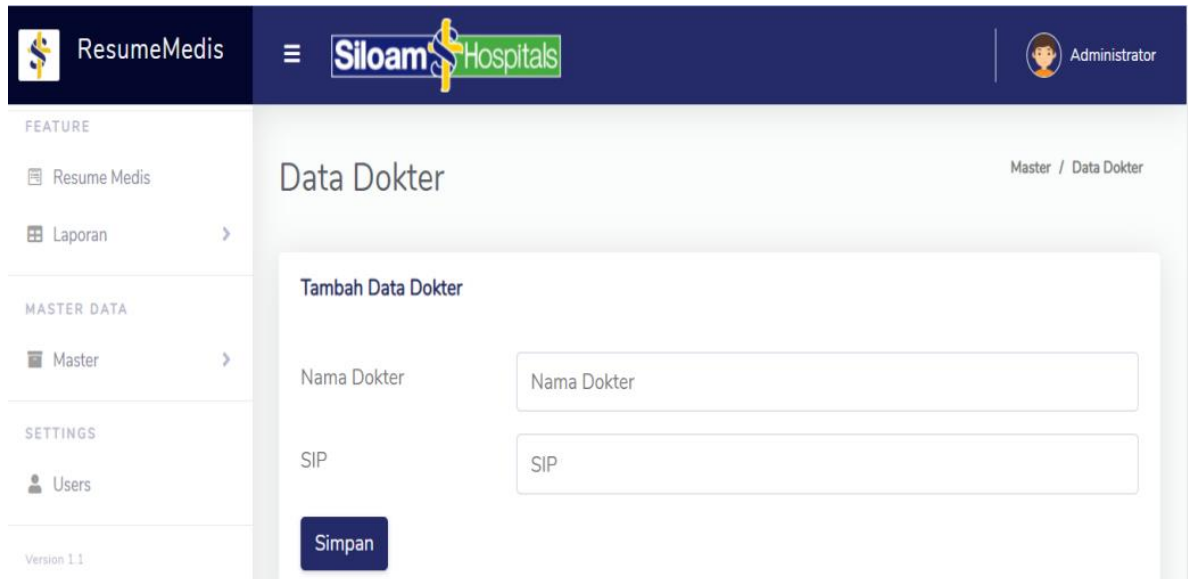

Gambar 14. Halaman Input Data Dokter

Halaman ini adalah tampilan yang berisikan form untuk menginput data dokter Petunjuk pemakaian: 
1. Halaman akan muncul jika menekan tombol Tambah Data dihalaman data dokter

2. Masukan Nama dan SIP

3. Tekan enter atau klik tombol simpan untuk menyimpan data

\section{Halaman Master Data Pasien}

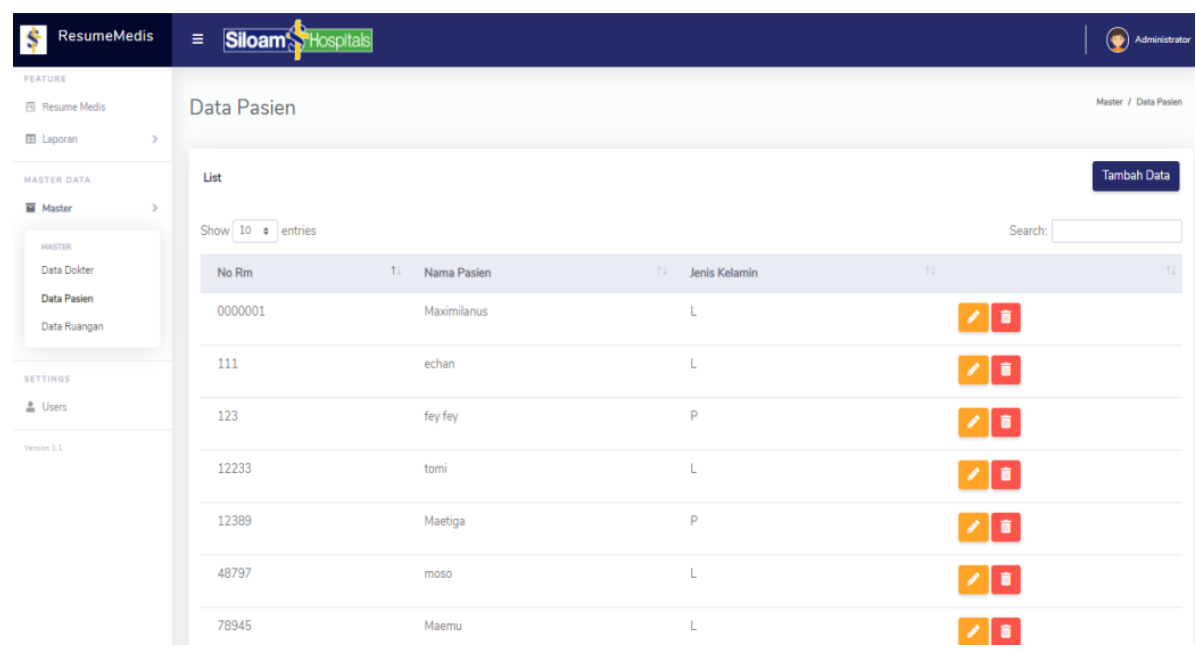

Gambar 15. Halaman Master Data Pasien

Halaman ini adalah tampilan berisikan data-data pasien yang sudah terinput.

Petunjuk pemakaian:

1. Halaman ini akan muncul jika menekan menu Master, data Pasien pada sidebar menu

2. Tombol Tambah Data untuk menginputkan data pasien

3. Textbox untuk melakukan pencarian data pasien

4. Tombol ikon pensil untuk mengubah data pasien yang terdiri dari nama pasien dan jenis kelamin

5. Tombol ikon tempat sampah untuk menghapus data pasien

\section{Halaman Input Data Pasien}

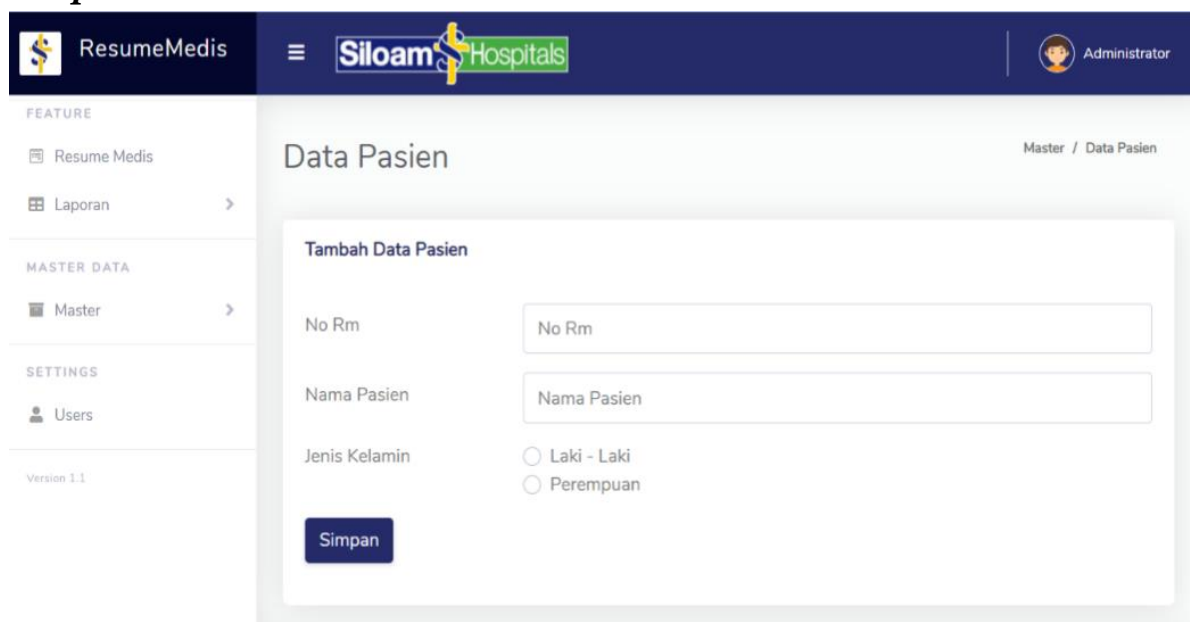

Gambar 16. Halaman Input Data Pasien

Halaman ini adalah tampilan yang berisikan form untuk menginput data pasien. 
Risa Juli Saputra, Sali Setiatin, Yuda Syahidin

Petunjuk pemakaian:

1. Halaman ini akan muncul jika menekan tombol Tambah Data dihalaman data pasien

2. Masukan No RM, nama pasien dan jenis kelamin

3. Tekan enter atau klik tombol simpan untuk menyimpan data.

\section{Halaman Master Data Ruangan}

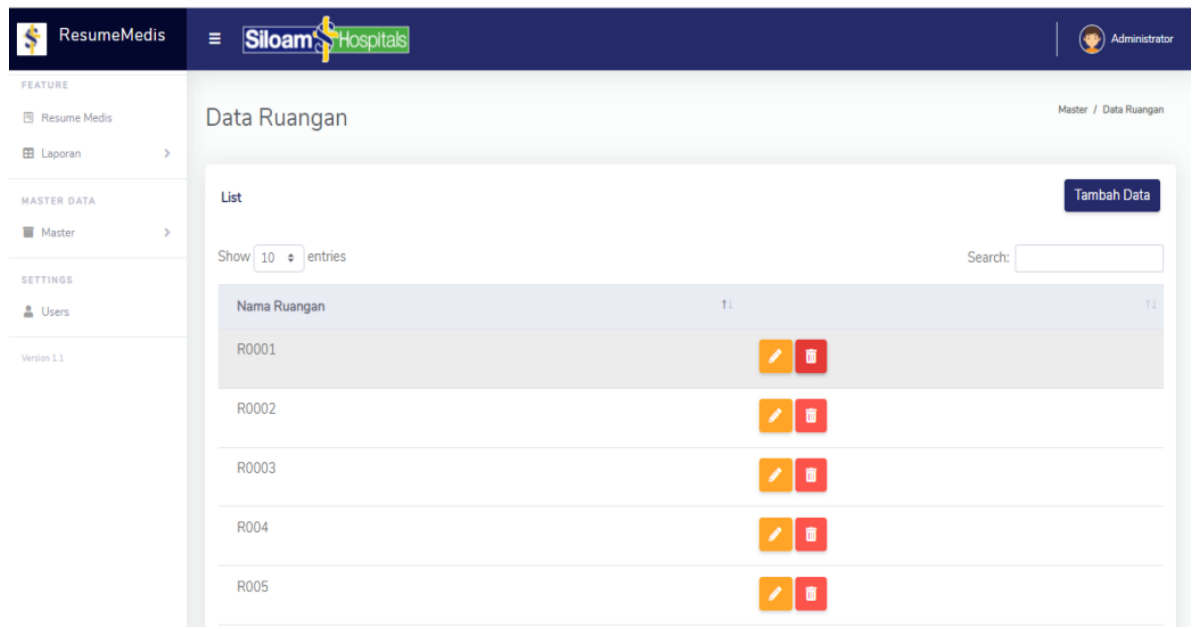

Gambar 17. Halaman Master Data Ruangan

Halaman ini adalah tampilan yang berisikan data ruangan yang sudah terinput. Petunjuk pemakaian:

6. Halaman ini muncul jika menekan menu Master, data Ruangan pada sidebar menu

7. Tombol Tambah Data untuk menginputkan data ruangan

8. Textbox untuk melakukan pencarian data ruangan

9. Tombol ikon pensil untuk mengubah data ruangan yang terdiri dari nama ruangan

10. Tombol ikon tempat sampah untuk menghapus data ruangan.

\section{Halaman Input Data Ruangan}

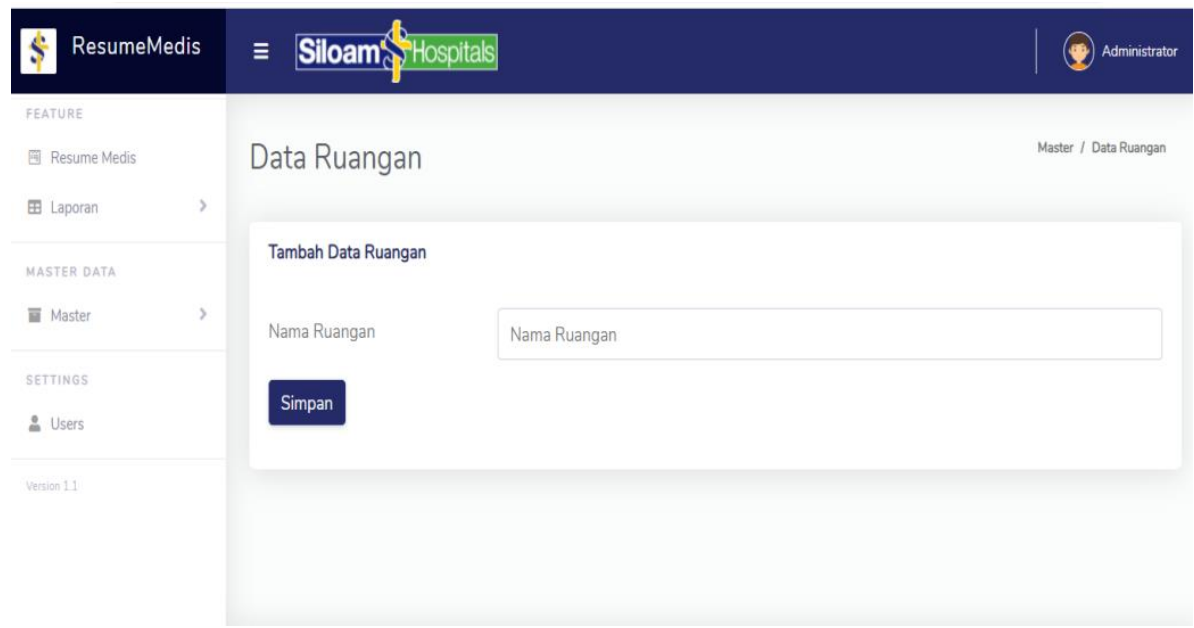

Gambar 18. Halaman Input Data Ruangan

Halaman ini adalah tampilan yang berisikan form untuk menginput data ruangan 
Petunjuk pemakaian:

4. Halaman ini muncul jika menekan tombol Tambah Data dihalaman data ruangan

5. Masukan nama ruangan

6. Tekan Enter atau klik tombol simpan untuk menyimpan data

\section{Kesimpulan}

Petugas anasis rekam medis di Siloam Hospitals Purwakarta sudah menggunakan komputerisasi untuk menganalisis kelengkapan rekam medis khususnya formulir resume medis pasien rawat inap namun masih menggunakan penginputan data manual pada excel dan belum ada aplikasi khusus. Sehingga, kemungkinan dapat terjadi kekeliruan dalam penginputan dan pelaporannya. Oleh karena itu, perlu adanya perancangan sistem informasi khusus untuk menganalisis kelengkapan formulir resume medis pasien rawat inap. Dengan adanya perancangan sistem informasi ini diharapkan dapat membantu dan mempercepat perekam medis dibagian anasisi dalam menginput, penganalisis, melaporkan serta dapat meminimalisir kekeliruan dan ketidakakuratan yang terjadi. Pencatatan dan pelaporan data yang sudah terkomputerisasi juga membuat data lebih aman dalam penyimpanannya, sehingga petugas tidak perlu takut data akan hilang atau rusak. Selain itu dengan adanya perancangan sistem ini tidak akan memakan banyak tempat.

Kelengkapan rata-rata keseluruhan isi resume medis pasien rawat inap di Siloam Hospitals Purwakarta sudah cukup baik dengan jumlah persentase yang lengkap sebesar 65\% dan tidak lengkap sebesar 35\% dari 200 sampel berkas rekam medis. Saran yang dapat diberikan oleh penulis kepada manajemen Siloam Hospitals Purwakarta yaitu sebaiknya rumah sakit memiki sistem informasi yang lebih modern didalam pengelolahan data, agar terwujudnya rekam medis yang lengkap sebaiknya dilakukan sosialisasi, pelatihan dan pemantaun yang lebih tentang SOP (Standar Operasional Prosedur) pengisian formulir resume medis, sebaiknya rumah sakit melakukan concurrent analysis yaitu analisis yang dilakukan pada saat pasien masih dirawat atau selama perawatan berlangsung yang dilakukan di ruang perawatan dengan tujuan untuk meminimalisir ketidaklengkapan pengisian rekam medis. Saran ini diberikan oleh peneliti agar setiap pasien merasa nyaman dengan informasi yang akurat, manfaat lain yang dapat diperoleh oleh rumah sakit yaitu dengan data yang lengkap memiliki data outentik didepan hukum dan yang terpenting agar rumah sakit lebih siap untuk menghadapi akreditasi berdasarkan SNARS.

Harapan dari penulis semoga perancangan sistem informasi resume medis pasien rawat inap ini dapat bermanfaat bagi rumah sakit agar mempermudahkan pekerjaan para perekam medis dibagian analisis resume medis panien. 


\section{Bibliografi}

Hatta, Gemala R. (2012). Pedoman Manajemen Informasi Kesehatan di Sarana Pelayanan Kesehatan: Revisi Buku Petunjuk Teknis Penyelenggaraan Rekam Medis. Medical Record Rumah Sakit (1991) Dan Pedoman Pengelolaan Rekam Medis Rumah Sakit Di Indonesia (1994, 1997), Edk, 2.

Jaya, Susanti Tria, Wulandari, Ratna Feti, \& Susiloningtyas, Luluk. (2021). Pendidikan Kesehatan PHBS Kader Kesehatan Era New Normal di Desa Darungan. Journal of Community Engagement in Health, 4(1), 162-166.

Kurniati, Dewi. (2019). Penerapan Management K3RS.

Prasetyo, Agung, \& Azis, Mohammad Syamsul. (2018). Perancangan Sistem Informasi Rekam Medis Pada Puskesmas Jomin Berbasis Web. Jurnal Interkom: Jurnal Publikasi Ilmiah Bidang Teknologi Informasi Dan Komunikasi, 13(2), 31-38.

Putra, Dedi Karunia, \& Rohmadi, Sri Mulyono. (2013). Perancangan Sistem Informasi Pendaftaran Pasien Rawat Jalan Di Klinik Dr. Sri Widatik Sukoharjo Berbasis Web, 7(2), 18-36.

Ramadani, Niska, \& Heltiani, Nofri. (2019). Perancangan Sistem Informasi Rekam Medis Puskesmas Sukamerindu. Edik Informatika, 6(1), 55-64.

Rangga, Rangga, Syahidin, Yuda, \& Hidayati, Meira. (2021). PERANCANGAN SISTEM INFORMASI KELENGKAPAN REKAM MEDIS RAWAT JALAN DENGAN METODE V-MODEL. Jurnal Sistem Informasi Dan Sains Teknologi, $3(2)$.

Rojabi, Ahmad Ridho. (2019). Blended Learning via Schoology as a Learning Management System in Reading Class: Benefits and Challenges. Jurnal Linguistik Terapan, 9(2), 36-42.

Sasmito, Ginanjar Wiro. (2017). Penerapan Metode Waterfall Pada Desain Sistem Informasi Geografis Industri Kabupaten Tegal. Jurnal Informatika: Jurnal Pengembangan IT, 2(1), 6-12.

Sugiyono, Metode. (2014). Penelitian Pendidikan Pendekatan Kuantitatif Kualitatif R\&D cet. Ke-19, Bandung: Alfabeta.

Syahidin, Yuda, \& Trioktafiani, Yuri. (2019). PERANCANGAN SISTEM INFORMASI PASIEN APPOINTMENT RAWAT JALAN BERBASIS WEB. Jurnal Cendikia, 18(1), 338-342.

Taryanto, Ardi, \& Handayani, Lilis Nur. (2019). Pengembangan Sistem Informasi Retensi Rekam Medis di Rumah Sakit Dustira Cimahi. Jurnal E-KOMTEK (ElektroKomputer-Teknik), 3(2), 62-70. 
Perancangan Sistem Informasi Resume Medis Pasien Rawatinap di Siloam Hospitals Purwakarta

Wirajaya, Made Karma, \& Nuraini, Novita. (2019). Faktor Faktor yang Mempengaruhi Ketidaklengkapan Rekam Medis Pasien pada Rumah Sakit di Indonesia. Jurnal Manajemen Informasi Kesehatan Indonesia (JMIKI), 7(2), 165. 